\title{
Antagonistic Endosymbion Bacteria against Soft-Rot Bacteria in Phalaenopsis sp.
}

\author{
Dewi Nur Anggraeni ${ }^{1}$, Eti Sumiati ${ }^{2}$ \\ ${ }^{1}$ Faculty of Biology, Universitas Medan Area, Indonesia. 20223 \\ ${ }^{2}$ Department of Health, Sekolah Tinggi Ilmu Kesehatan Mataram, Indonesia. 83116 \\ \{dewinur@staff.uma.ac.id ${ }^{1}$, sumiatie070@gmail.com²\}
}

\begin{abstract}
In orchid plants, bacteria that cause soft rot enter the plant tissue through wounds, causing soft rot to thrive in the plant tissue. Symptoms of soft rot in orchids are characterized by the appearance of blackish brown spots, leaves become runny and leaves become soft, turgor pressure on the leaves disappears, and produces a foul odor. Decay that occurs in young plant tissue quickly compared to adult plant tissue. The purpose of this study was to determine the antagonistic properties of endosymbiotic bacteria against soft rot bacteria tested on Phalaenopsis sp. The research method used was in vivo, namely the Phalaenopsis sp. orchid plant introduced with endosymbiotic bacteria then tested using soft rot bacteria. The results of this study were obtained on the soak + flush test treatment.
\end{abstract}

Keywords: Soft-Rot, Endosymbiont, Phalaenopsis sp.

\section{Introduction}

Soft rot bacteria, bacteria that cause soft rot, the main species that cause soft rot in orchids are Pseudomonas vinidiflava, Dickeya dadantii, Pectobacterium carotovorum subsp. carotovorum and Burkholderia sp. (Gnanamanickam, 2006). Symptoms of bacterial infection, Soft rot can spread widely and spread to the top of plants and at the growing point (meristem tissue) of a plant, this spread occurs in humid environments and the impact is quickly causing death in plants (Semangun, 2004). Symptoms of soft rot that attack orchids can be seen in Figure 1 as follows:

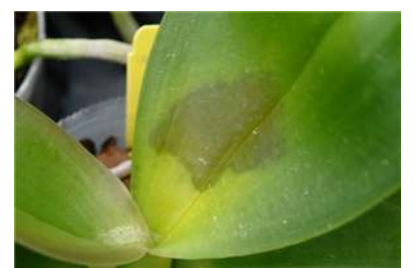

Figure 1. Symptoms of soft rot in orchids Phalaenopsis sp.

Areas of distribution of soft rotten bacteria, Soft rot bacteria have a wide distribution area in almost all the world. Soft rot is spread from temperate, subtropical to tropical regions. Endosymbionic bacteria are one group of bacteria that live in symbiosis with plants without 
harming their hosts (Kobayashi et al., 2000). Endosymbionic bacteria are bacteria that part or all of their lives are in the living tissues of host plants (Petrini, 1992). Endosymbionic bacteria have an important role in the host plant tissue that shows mutualistic interactions, namely positive interactions with host plants and negative interactions with plant pests and diseases (Azevedo et al., 2000).

In general, endosymbionic bacteria occur at low population densities than rhizosphere bacteria or pathogenic bacteria (Rosenblueth and Romero, 2004). Endosymbionic populations are the same as populations of the rhizosphere, which are conditioned on biotic environments and abiotic environments (Seghers et al., 2004). Endosymbionic bacteria can well protect plants in biotic and abiotic environmental pressures rather than rhizosphere bacteria (Hallmann et al., 1997).

Endosymbionic bacteria contained in one host plant and are not limited in number, namely endosymbionic bacteria consisting of several genera and species in one plant. Endosimbion is more aggressive in plants and is able to replace the position of other bacteria (Verma et al., 2004). Endosymbionic bacteria are found in roots, stems, leaves, seeds, leaves, fruits and tubers (Benhizia et al., 2004).

Antibiotics are used as anti microbes, especially for infectious diseases caused by microbes. Antibiotics must have the highest selective toxicity possible, so they must be very toxic for microbes, but relatively not toxic for hosts (Gan and Setiabudy, 1987). Antibiotics can be produced by endosymbionic bacteria, which are found in plant tissues. The antibiotics obtained must have high activity against pathogenic microbes; low toxicity to animals, humans and plants; broad spectrum; good stability; and has pharmacokinetic characteristics (Dwidjoseputro, 2005).

Attempts to obtain antibiotic compounds are carried out by an in vivo process. Some endosymbionic bacteria produce antibiotics (Sessitsch et al., 2004) in the process, endosymbionic bacteria will secrete a secondary metabolite which is an antibiotic compound. The secondary metabolites produced are compounds synthesized by microbes. This metabolite is not used to fulfill its primary needs, which are growing and developing but is used to maintain its existence in interacting with its environment (Hartmann et al., 1985). The metabolites produced by endosymbionic bacteria are antibiotic compounds that can protect plants from attack by pathogenic pests and microbes, so they can be used as biocontrol agents (Wahyudi, 1997; Sumaryono, 1999).

The living colonies of endosymbion bacteria are microhabitat and are a useful source of metabolites in the fields of biotechnology, agriculture, and pharmacy. Some endosymbionic bacteria produce antibiotic compounds that actively affect pathogenic bacteria in humans, animals and plants (Petrini, 1992).

Microbes that live in nature are widespread, both living by direct contact with the environment and living in living tissues of humans, animals and plants. Pathogen resistance to some anti-microbial substances has triggered an attempt to find new effective anti microbial agents (Kuc, 1983).

In conjunction with plant resistance, many plant studies have been investigated that are related to infections of other microorganisms (bacteria or fungi). This resistance is called Induced resistance. The idea of obtaining this induced resistance is based on the immunization process in humans, and is practiced in certain parts of the plant which is inoculated by a pathogen or weak pathogen, so that the plant produces a defense system so that the plant will be resistant to more pathogenic attacks virulent, or even resistant to other pathogens (Kuc, 1983).

According to Misaghi (1982) induced resistance occurs due to physical, chemical, or biotic agents before infection or pathogenic inoculation. Resilience like this by Kuc (1983) is said to 
be synonymous with immunization, and Misaghi (1982) identifies it with Cross Protection. Endosymbionic bacteria can suppress proliferation of nematodes and can be used in rotation or rotation with other host plants (Sturz and Kimpinski, 2004).

Plant resistance is much related to the physiological processes of plants, so all factors that influence plant physiology will also affect the resilience. Some of these factors include plant age, temperature, day length, light intensity and quality, mineral materials, plant hormones, damage, the presence of microorganisms (bacteria, fungi, viruses), or the presence of infection (Kuc, 1983).

\section{Material and Methods}

\section{a. Test for Orchid Seed Resilience Results of the Introduction of Endosymbionic Bacteria to Soft Rot}

Orchid Phalaenopsis sp. treated soaked, watered, soaked and watered, injected using a bacterial suspension of endosymbion with a concentration of bacteria as much as $10^{8} \mathrm{cfu} /$ $\mathrm{ml}$. For immersion treatment, Phalaenopsis sp. Orchids. soaked for 30 minutes in the suspension of endosymbionic bacteria $10^{8} \mathrm{cfu} / \mathrm{ml}$. Watering every 2 weeks by watering Phalaenopsis sp. Orchids. using a suspension of $10^{8} \mathrm{cfu} / \mathrm{ml}$ endosymbion bacteria. Soaking and watering treatment, the first thing to do is Phalaenopsis sp. soaked for 30 minutes with a suspension of $10^{8} \mathrm{cfu} / \mathrm{ml}$ endosymbion bacteria, then 2 weeks later a suspension of $10^{8}$ $\mathrm{cfu} / \mathrm{ml}$ endosymbion bacteria was doused. The injection treatment was carried out on the orchid stem of Phalaenopsis sp. when the new orchid is removed from the bottle and dried it is then injected with a suspension of $10^{8} \mathrm{cfu} / \mathrm{ml}$ endosymbion bacteria. After passing the acclimatization process for 2 months Phalaenopsis sp. Orchids. Inoculated with soft rotcausing bacteria (Phsl2 isolate) as much as $10^{8} \mathrm{cfu} / \mathrm{ml}$ of soft rot and orchids incubated in a greenhouse. Observations were carried out for 2 weeks and analyzed by plant resistance scoring.

\section{Analysis of Plant Resilience}

Endurance analysis was obtained from the calculation of the intensity of soft rot disease number with the following formula:

$$
\mathrm{I}=\frac{\sum(\mathrm{nxv})}{\mathrm{ZxN}} \times 100 \%
$$

Information :

$\mathrm{I}=$ Attack intensity

$\mathrm{N}=$ Total number of leaves

$\mathrm{n}=$ Number of leaves attacked at each scale value

$\mathrm{v}=$ Scale value for each leaf

$\mathrm{Z}=$ highest scale value

Determination of scale values is carried out according to Norman et al. (1997) as follows:

$0=$ asymptomatic

$1=$ small patch $1 \%$ of leaf area

$3=$ spotting $2-10 \%$ of leaf area

$5=$ spreading rather $11-25 \%$ of leaf area

$7=$ patches extending $26-50 \%$ of leaf area

$9=$ blots spread over $50 \%$ or leaves fall out 
After that scoring is done or determining the resistance criteria for orchid plants Phalaenopsis sp. against soft rot in Table 2 based on the intensity of the disease attack proposed by Joko et al. (2012):

Table 1. Determination of endurance criteria for orchid plants Phalaenopsis sp.against soft rot

\begin{tabular}{|c|c|}
\hline Disease Intensity & Criteria \\
\hline 0 & Imune \\
\hline $0 \%<\mathrm{x}<25 \%$ & Resisten \\
\hline $25 \%<\mathrm{x}<50 \%$ & Rather Resistant \\
\hline $50 \%<\mathrm{x}<75 \%$ & Rather Vulnerable \\
\hline $75 \% \leq \mathrm{x} \leq 100 \%$ & Vulnerable \\
\hline
\end{tabular}

\section{Results and Discussion}

Orchids that have been introduced with endosymbionic bacteria for 2 months, then inoculated with bacteria that cause soft rot in the orchid. The results of this introduction can induce plant resistance in orchids as a test material. Plant resistance is seen based on how much the plant is resistant to disease attacks. The size of the disease attack is obtained based on the calculation of the intensity of the disease, the calculation results can be seen in Table 2.

Table 2. Average calculation of disease intensity in Phalaenopsis sp. Orchids.

\begin{tabular}{|c|c|c|c|c|c|c|c|}
\hline \multirow{2}{*}{ Treatment } & \multicolumn{7}{|c|}{ Disease Intensity } \\
\cline { 2 - 8 } & Day-1 & Day-2 & Day-3 & Day-4 & Day-5 & Day-6 & Day-7 \\
\hline I & $0 \%$ & $5 \%$ & $10 \%$ & $10 \%$ & $10 \%$ & $10 \%$ & $10 \%$ \\
\hline II & $0 \%$ & $4 \%$ & $12 \%$ & $12 \%$ & $12 \%$ & $19,11 \%$ & $19,11 \%$ \\
\hline III & $0 \%$ & $13 \%$ & $13 \%$ & $18 \%$ & $18 \%$ & $18 \%$ & $18 \%$ \\
\hline IV & $0 \%$ & $15 \%$ & $27 \%$ & $35 \%$ & $35 \%$ & $37,78 \%$ & $37,78 \%$ \\
\hline V & $0 \%$ & $0 \%$ & $0 \%$ & $0 \%$ & $0 \%$ & $0 \%$ & $0 \%$ \\
\hline VI & $0 \%$ & $0 \%$ & $0 \%$ & $0 \%$ & $0 \%$ & $0 \%$ & $0 \%$ \\
\hline VII & $33,33 \%$ & $43,55 \%$ & $100 \%$ & $100 \%$ & $100 \%$ & $100 \%$ & $100 \%$ \\
\hline \multirow{2}{*}{ Treatment } & Day-8 & Day-9 & Day-10 & Day-11 & Day-12 & Day-13 & Day-14 \\
\hline & $30 \%$ & $40 \%$ & $40 \%$ & $40 \%$ & $40 \%$ & $40 \%$ & $40 \%$ \\
\hline I & $36 \%$ & $36 \%$ & $36 \%$ & $36 \%$ & $36,44 \%$ & $36,44 \%$ & $45,33 \%$ \\
\hline II & $28 \%$ & $28 \%$ & $28 \%$ & $28 \%$ & $33,78 \%$ & $33,78 \%$ & $37,78 \%$ \\
\hline III & $55 \%$ & $65 \%$ & $65 \%$ & $65 \%$ & $65 \%$ & $65 \%$ & $65 \%$ \\
\hline IV & $0 \%$ & $0 \%$ & $0 \%$ & $0 \%$ & $0 \%$ & $0 \%$ & $0 \%$ \\
\hline V & $0 \%$ & $0 \%$ & $0 \%$ & $0 \%$ & $0 \%$ & $0 \%$ & $0 \%$ \\
\hline VI & $100 \%$ & $100 \%$ & $100 \%$ & $100 \%$ & $100 \%$ & $100 \%$ & $100 \%$ \\
\hline VII
\end{tabular}

From Table 2 it can be graphed the average intensity of diseases that occur in Phalaenopsis sp. Orchids. can be seen in Figure 2: 


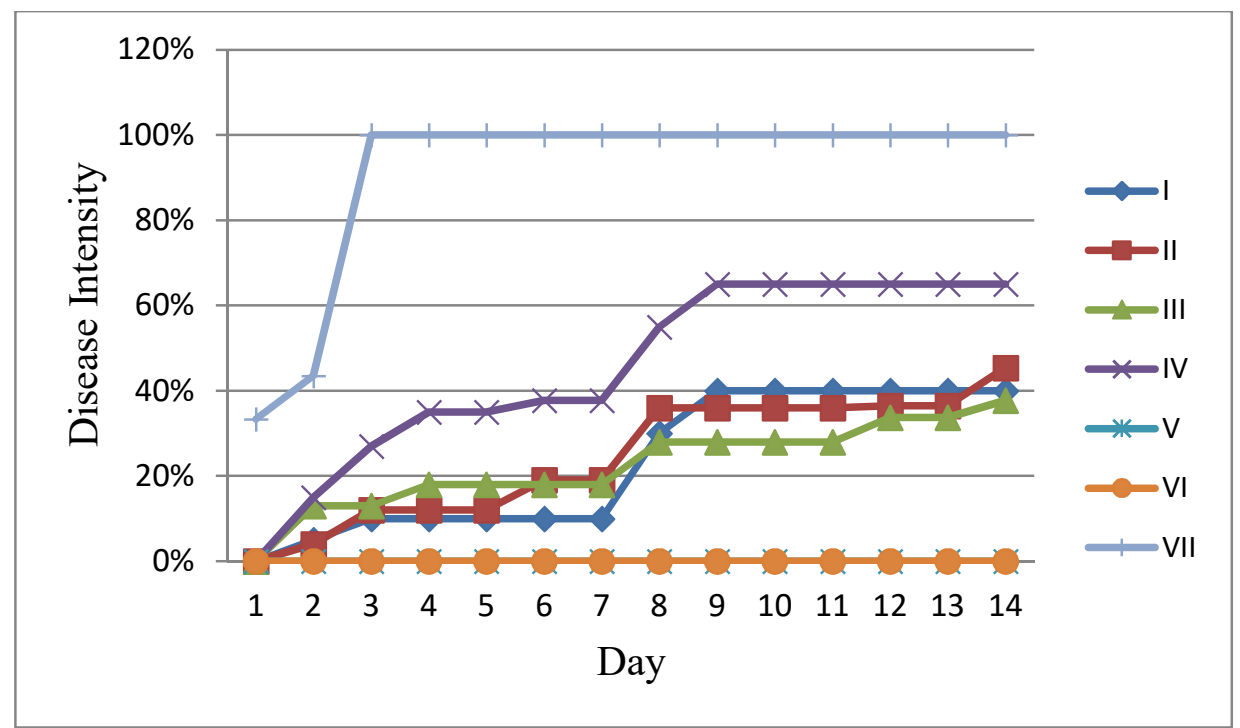

Figure 2. Average disease intensity in Phalaenopsis sp. Orchids.

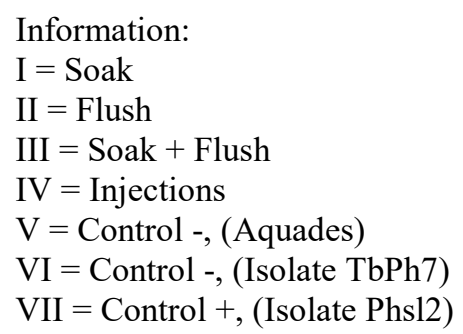

From Figure 2 it can be seen that there is an increase in the intensity of soft rot in Phalaenopsis sp. Orchids. From several values of the intensity of the disease scoring was carried out to determine the resistance of orchid plants Phalaenopsis sp. which has been induced with endosymbionic bacteria. Results can be seen starting from day 1 to day 14 .

At week 1 (day 7) can be seen in treatment I (soak), II (flush), and III (soak + flush) has a low disease intensity value which is below $20 \%$. According to the results of this score scoring is included in the resistant category. While at the second week (14th day) treatment I (soak) and treatment II (flush) the value of the intensity of the disease increased to below $50 \%$, and entered the category of somewhat resistant. In treatment III (soak + flush) the value of the disease intensity was lower than that of treatment I, and II which was $37.78 \%$, the scoring value obtained was also categorized as somewhat resistant. The resistance of this plant can arise due to the introduction of endosymbionic bacteria, so that the Phsl2 bacteria do not develop rapidly and are inhibited by growth of endosymbionic bacteria in orchids Phalaenopsis sp. For treatment IV (injection) at week 1 the value of the disease intensity was $37.78 \%$ with the category rather resistant and increasing at the second week (day 14) the value became $65 \%$, with the category rather vulnerable, at IV treatment (injection), the resistance of plants that appear is not too good because it has been categorized as a rather vulnerable, and many plants are attacked by soft rot. In treatment $\mathrm{V}$ \{control (-) that is by giving aquades\} and treatment VI \{control (-), given endosymbion bacteria on leaves that have been inoculated with bacteria causing soft rot disease 
has a value of $0 \%$ disease intensity and falls into the immune category, because the orchid plants Phalaenopsis sp. those that have been inoculated do not show symptoms of disease and the results of inoculation do not develop on the leaves, only in the form of spots (black spots).

In treatment $\mathrm{V}$ \{control (-) that is by giving aquades\} and treatment VI \{control (-), given endosymbion bacteria on the leaves that have been inoculated with bacteria causing soft rot\} there are no soft rot bacteria that spread in orchid plants, spot (black spots) only shows the occurrence of a hypersensitive response mechanism. According to Agrios (2005) hypersensitive response is a very specific response and only occurs when products from the pathogen avirulence gene interact with plant resistance gene products. This response is in the form of cell death with the aim of limiting the development of pathogenic infections into plant cells, activating the formation of phytoalexin, salicylic acid and signal transduction so as to give rise to systemic resistance (SAR).

In treatment VII control $(+)$ given phs12 isolate which is a bacteria that causes soft rot disease $\}$ on orchid plants Phalaenopsis sp. directly affected by the disease and has the highest intensity value of $100 \%$ and after scoring is categorized as vulnerable on the 3 rd day to the 14 th day. In treatment VII, there was no treatment for the introduction of endosymbion bacteria which was given so that the plants were susceptible to soft rot.

In these results it can be seen that treatment III (soak + flush) is the best treatment among other treatments with the level of disease intensity below $40 \%$ on day 14 and the scoring results state that the plants in the category are rather resistant. The image of treatment III (soak + flush) can be seen in Figure 3.

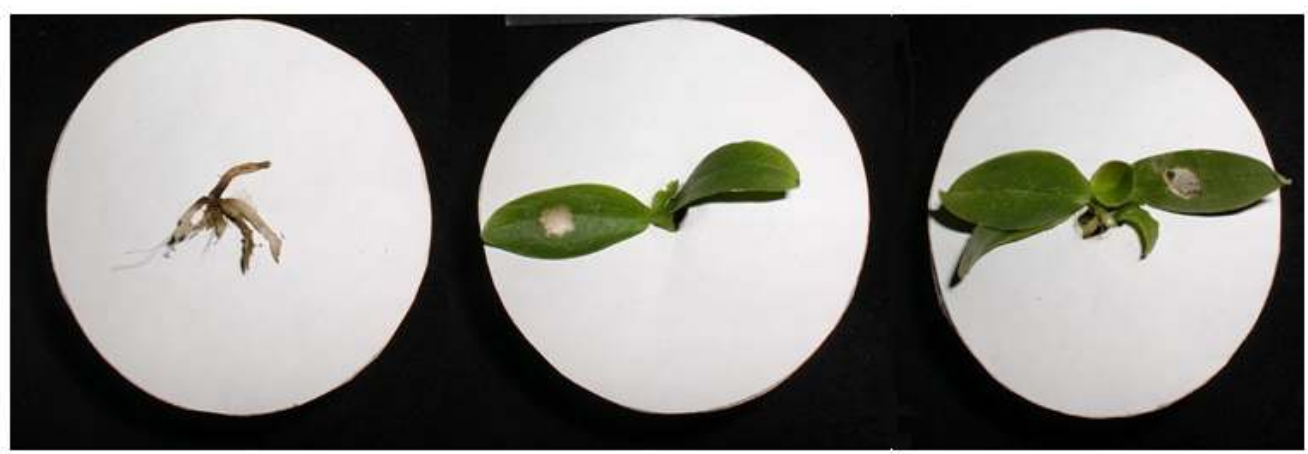




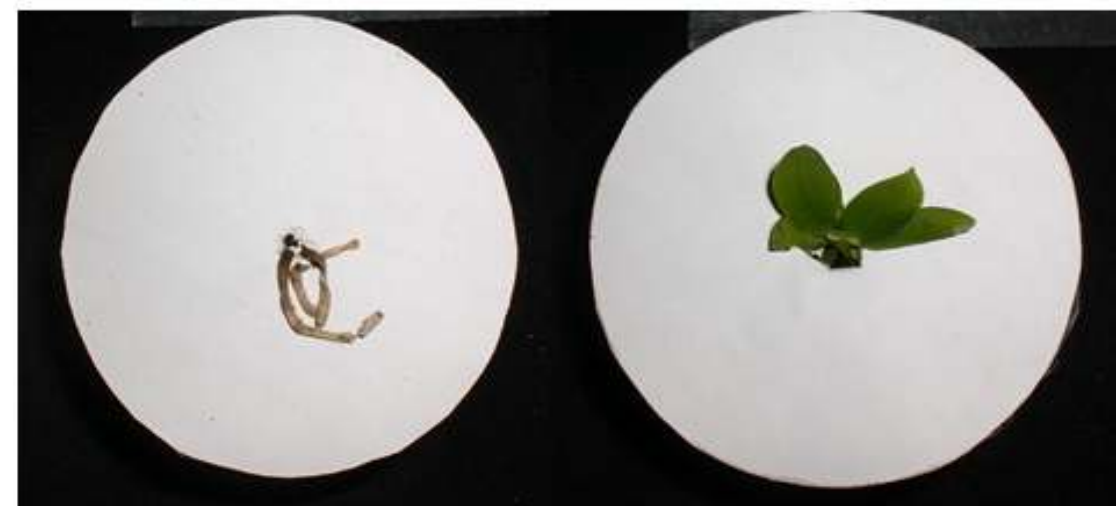

Figure 3. Treatment III (soak + flush).

\section{Conclusion}

The treatment given with the introduction of endosymbionic bacteria in a variety of treatments shows an increase in the resistance of orchid plants Phalaenopsis sp. against soft rot. Most of the results of plant resistance tests included in the category of mildly resistant to soft rot disease compared to orchid plants Phalaenopsis sp. which is not given endosymbionic bacteria.

\section{References}

[1] Agrios, G.N. 2005. Plant Pathology, 3rd. Academic Press. Sandiego, Ed: Busnia, M. Ilmu Penyakit Tumbuhan, Gadjah Mada University Press, Yogyakarta.

[2] Joko, T., Subandiyah, S., Daryono, B.S., Anggraeni, D.N., Irianti, M., and Hanudin. 2012. Isolation of Endophytic Bacteria From Orchids and Their Antibacterial Activity Against Soft-rot Pathogen. The International Symposium on Orchids And Ornamental Plants (17).

[3] Norman, D.J., Henny, R.J., dan Yuen, J.M.A. 1997. Disease Resistance in Twenty Dieffenbachia cultivars. Hort Science 32 (4):709-710.

[4] Kuc, J. 1983. Induced Systemic Resistance in Plant Caused by Fungi and Bacteria, pp: 192-221 dalam B.J. Deveral (Eds.), The Dynamics Host Devence. Acad. Press, Sydney, New York, London.

[5] Sturz, A., and Kimpinski, J. 2004. Endophytic Root Bacteria Derived from Marigolds (Tagetes spp.) can Decrease Soil Population Densities of Rootlesion Nematodes in The Potato Root Zone. Plant Soil, 262:241-249

[6] Misaghi, I.J. 1982. Physiology and Biochemistry of Plant Pathogen Interactions, p: 144-187. Plenun, New York and London.

[7] Petrini, O. 1992. Metabolite Production, and Substrate Utilization in Endophytic Fungi. Wiley Liss Inc., Swiss, Natural toxins 1: 185-196. 
[8] Sumaryono, W. 1999. Produksi Metabolit Sekunder Tanaman secara Bioteknologi. Direktorat Teknologi Farmasi dan Medika, BPPT, Jakarta, ISBN : 979-8768-02-7, 3848. Tomita F. Screening of useful strains.

[9] Wahyudi. 1997. Teknik Skrining Mikrobia Endofit Penghasil Antibotik. Subdirektorat Bioteknologi, BPPT, Jakarta.

[10] Sessitsch, A., Reiter, B., and Berg, G. 2004. Endophytic Bacterial Communities of Field-Grown Potato Plants and Their Plant-Growth-Promoting and Antagonistic Abilities. Can. J. Microbiol. 50:239-249.

[11] Hartmann, A., Stoffels, M., Eckert, B., Kirchhof, G., and Schloter, M. 1985. Analysis of The Presence and Diversity of Diazotrophic Endophytes, Pages 727-736 in: Prokaryotic Nitrogen Fixation: A Model System for Analysis of a Biological Process. Horizon Scientific Press, Wymondham, U.K.

[12] Dwidjoseputro, D. 2005. Dasar-Dasar Mikrobiologi, page 103. Djambatan, Malang.

[13] Gan S, Setiabudy R, dan Sjamsudin U. 1987. Farmakologi dan Terapi, edisi III, Fakultas Kedokteran, Universitas Indonesia, Jakarta; 514.

[14] Benhizia, Y., Benhizia, H., Benguedouar, A., Muresu, R., Giacomini, A., and Squartini, A. 2004. Gamma Proteobacteria can Nodulate Legumes of The Genus Hedysarum. Syst. Appl. Microbiol. 27:462-468.

[15] Verma, S. C., Singh, A., Chowdhury, S. P., and Tripathi, A. K. 2004. Endophytic Colonization Ability of Two Deep-Water Rice Endophytes, Pantoea sp. and Ochrobactrum sp. Using Green Fluorescent Protein Reporter. Biotechnol. Lett. 26:425-429.

[16] Rosenblueth, M., and Martinez, R.E. 2004. Rhizobium Etli Maize Populations and Their Competitiveness for Root Colonization. Arch. Microbiol. 181:337-344.

[17] Seghers, D., Wittebolle, L., Top, E. M., Verstraete, W., and Siciliano, S. D. 2004. Impact of Agricultural Practices on The Zea mays L. Endophytic Community. Appl. Environ. Microbiol. 70:1475-1482.

[18] Hallmann, J., Quadt-Hallmann, A., Mahaffee, W. F., and Kloepper, J. W. 1997. Bacterial Endophytes in Agricultural Crops. J. Microbiol. 43:895-914.

[19] Kobayashi, D. Y., and Palumbo, J. D. 2000. Bacterial Endophytes and Their Effects on Plants and Uses in Agriculture, p. 199-233. In C. W. Bacon and J. F. White (ed.), Microbial endophytes. Marcel Dekker, Inc., New York, N.Y.

[20] Gnanamanickam, S.S. 2006. Plant-Associated Bacteria, page 42. University of Madras, Chennai, India.

[21] Azevedo J.L, Pereira J.O, de Araujo W.L. 2000. Plant Biotechnology Enviromental Biotechnology, Endophytic Microorganisms : a Review on Insect Control and Recent Advances on Tropical Plants. Electronic Journal of Biotechnology. 3(1):2-9. 